\title{
Performance of Islamic and conventional stock indices: empirical evidence from an emerging economy
}

Md Ejaz Rana and Waheed Akhter ${ }^{*}$

\author{
* Correspondence: \\ drwaheed@ciitlahore.edu.pk \\ Center of Islamic Finance, \\ Department of Management \\ Sciences, COMSATS Institute of \\ Information Technology, Lahore, \\ Pakistan
}

\begin{abstract}
Background: This study aims to investigate the extent to which the conditional volatilities of both Shari'ah compliant stock and conventional stock are related to those of interest rate and exchange rate in the emerging economy of Pakistan.

Methods: We used KMI 30 and KSE 100 indices for Islamic and conventional stock for the period of July 2008 to November 2013. We employed Generalized Autoregressive Conditional Heteroskedastic in the mean (GARCH-M) model. This framework relaxes constancy assumption of classical linear regression (CLRM) model and allows exchange rate and interest rate volatility to evolve over time. The GARCH$M$ framework also reveals results about risk-return trade-off in the context of both Islamic and conventional stock indices.

Results: The findings show positive and statistically significant effect of interest rate volatility on KSE-100, whereas KMI-30 remains unaffected by the same. Exchange rate volatility is found to be significant for both conventional and Islamic indices. The relationship of risk coefficient $(\gamma)$ and stocks returns, as expected, is positive and statistically significant for both KMI-30 and KSE-100. This result is consistent with the theory of risk-return trade-off. The results of parametric t-test show significant difference between returns of both indices. This implies that Shari'ah compliant stock index (KMI-30) of Pakistan underperforms its conventional counterpart.

Conclusion: By using different performance measures (Sharp ratio, Jensen alpha, Treynor ratio), this study also investigates the hypothesis that Islamic stock index has inferior performance compared with unscreened conventional counterparts due to availability of a smaller investment universe, increased monitoring costs, and limited diversification.
\end{abstract}

Keywords: KMI-30, KSE-100 Index, Shari'ah, Exchange rate volatility, Interest rate volatility, Stock Performance etc

\section{Background}

The Shariah screenings criteria applied by the Islamic scholars have enabled Shariah Complaint Stock Indices to distinguish themselves from conventional stocks indices. In general, there are two Shariah screening criteria - positive and negative. Positive screenings allow an Islamic index to include those companies that meet certain Islamic ethical indicators (both quantitative and qualitative) whilst negative screenings delete stocks which are unable to meet such requirements. The common stock guidelines,

\section{Springer}

(c) 2015 Rana and Akhter. Open Access This article is distributed under the terms of the Creative Commons Attribution 4.0 International License (http://creativecommons.org/licenses/by/4.0/), which permits unrestricted use, distribution, and reproduction in any medium, provided you give appropriate credit to the original author(s) and the source, provide a link to the Creative Commons license, and indicate if changes were made. 
accepted by Shariah scholars, have become a key factor in the growth of Islamic funds all over the world. Majority of the Shariah scholars are agreed that buying and selling of stocks \&shares adhere to Shariah laws because shares \& stocks represent real assets. In addition, the dividend payments are also in accordance with Shariah indicators since receipt/payment of interest (Riba) is unlawful (Haraam) in Islam. Hence, equities, mutual funds, and government bonds are considered more compatible with Shariah screenings criteria of profit and risk sharing than fixed income assets.

The researches in Islamic finance have always been interested in investigating the question whether returns earned by the investors of Islamic funds/indices are different from conventional funds investors. In addition, the researchers are also examining whether adhering to Shariah law creates any impact on the performance of Islamic funds /indices because such funds suffer from restricted assets selection, limited investment practices, and smaller investment universe, Hassan (2001). Fundamentally, there are essentially two opposing views regarding Shariah screening effects on returns earned by Islamic indices. Opponents of Islamic ethical investing argue that implementing Islamic screening may result in limited investment universe due to potential increase in volatility, reduced diversification, and monitoring costs. In particular, due to Islamic screening, stable blue chip and larger firms may be excluded (due to high leverage) from Islamic index and as a result, remaining firms tend to be smaller and prevent investors to have other attractive investment opportunities from further consideration, Guyot (2011).

On the other hand, advocates of Islamic investing argue that financial and Islamic ethical screens propose a good economic and social sense to evaluate potential investments. Islamic ethical investors can align their potential investments with their religious \& ethical beliefs that will not only give them peace of mind but also a lawful (Halaal) monetary reward. In addition, the empirical findings of Myers (1993), Fama and French (1998 and 2002), Shyam-Sunder and Myers (1999) argue that most profitable firms borrow least, therefore there exist a negative relationship between profitability and leverage. Hence, Islamic index can outperform its conventional counterpart because all firms included in the any Islamic Index have low leverage ratios.

Although Islamic funds have shown a massive growth over the past few decades, the empirical literature on the performance analysis of such funds is still at its initial stage. The limited literature provides somewhat mixed results regarding performance of Shariah screened funds/Indices compared to their un-screened counterparts. For example, Hakim and Rashidian (2002) analyzed the performance of Dow Jones Islamic Index (DJIM) against its conventional counterparts; Dow Jones world index (DJW) and Dow Jones Sustainability World index (DJS). They applied capital asset pricing model (CAPM) and reported that DJIM index has outperformed DJW but has underperformed DJS index. The same results are reported by Hussein and Omran (2005). This study documents that during entire bull period DJIM index has outperformed its counterpart, but has underperformed during the bear market period. On the other hand, Hoepner et al. (2011) examine performance differences of 62 Islamic equity funds collected from 20 different countries. They report that Islamic funds from 8 western nations are unable to outperform their equity benchmarks, whereas only 3 funds have, somehow, performed relatively well against their market benchmarks. In addition, Dharani and Natarajan (2011) find no significant differences between the performance 
of Indian Shariah compliant stocks and conventional stocks indices during the period of 2007 to 2011. They report that average return earned by Shariah compliant stocks is similar to conventional stocks returns.

To the best of our knowledge, our study is the first attempt towards analyzing the performance of Islamic index with its conventional counterpart in an emerging economy which is struggling to Islamize its monetary and financial system of the country Pakistan is one of those few emerging economies who started Islamization of monetary and financial system of the country in early 80s. As a result of Islamization efforts, Supreme Court of Pakistan, on 14 November 1991, declared bank interest as "Riba" and prohibited all types of interest prevailed in monetary and financial system of Pakistan. In July 2008, an Islamic Index (KMI 30) is launched with a view to provide a platform for ethical investors who seek to align their financial objectives with their religious beliefs and value systems. Beside increasing investor trust and enhancing their participation, KMI-30 index also serves as research tool for measuring performance of Shariah compliant stocks and strategic assets allocation procedure. In this regard, it is really need of the hour to assess the performance of Islamic index. This performance analysis will tell us whether Islamization of stocks index rewards its investors or not. In addition, it will also help us to know whether objectives of establishing Islamic index are fulfilled or not. This will also give us insight whether an emerging economy like Pakistan is better at offering ethical investment universe for its local and international investors as well. Therefore, our study is the first attempt of not only analyzing the performance of Islamic stock index of Pakistan but also its response to volatility effects caused by other macroeconomic variables such as interest rate and exchange rate.

Therefore, the primary objective of this study is two-fold: first, by using different riskadjusted performance measures such as Jensen's Alpha (1968), Sharp ratio (1966), Treynor Ratio (1965), and MM (1977), this study investigates the potential impact of Shariah screening on the performance of Karachi Meezan Index (KMI-30), traded at Karachi Stock Exchange (Pakistan), against its conventional counterparts Karachi Stock Exchange index (KSE-100). The study examines whether returns earned by ethical investors who trade Shariah compliant stocks (KMI-30) are different from conventional investors. Second, to examine the effects of volatilities of interest rate and exchange rate on KMI-30 index and its counterparts, this study employs Generalized Autoregressive Conditional Heteroskedastic in the mean (GARCH-M) model. This framework relaxes constancy assumption of classical linear regression (CLRM) model and allows exchange rate volatility and interest rate volatility to evolve over time. The GARCH-M framework also reveals results about riskreturn trade-off in the context of returns earned by Islamic and conventional investors.

\section{Literature review}

Contrary to the literature of Islamic banks and Islamic mutual funds, Islamic indices have not received high level of empirical research due to their shorter histories (El Khamlichi and Laaradh 2012). In addition, the performance comparison of Islamic indices against conventional counterparts is also complicated owing to different factors such as differences in size and industry-weighting (Fowler and Hope 2007). Therefore, earlier studies such as Naughton and Naughton (2000) use qualitative approach to discuss the initial stage of Islamic stock indices in terms of regulations, financial principles, and market framework. 
However, previous studies on the performance analysis of Islamic indices provide somewhat mixed results. This difference among the results can be attributed to different performance measures, sample data, and different benchmarks used by these studies. For example, Atta (2000) analyzed the performance of Dow Jones Islamic Index (DJIM) against market index and risk-free rate. He reports that DJIM has not only outperformed its conventional counterparts, but also offered more returns than risk-free rate. Same results are reported by Hassan (2001) where he investigated the performance of 6 Dow Jones Islamic indices. His results also confirm superior efficiency of Islamic indices against counterparts. On the contrary, Girard and Hassan (2005) do not find any significant performance differences between of Dow Jones Islamic indices and 7 Morgan and Stanley conventional indices. They use different performance measures to check the robustness of the results. From single factor CAMP to four factor conditional CAMP; they report that results remain same for the period of 1996-2005. They also report that growth and small stocks are core drivers of the positive performance for Islamic indices. The same results are reported by Dabeerru (2006) about the performance of Saudi Arabian Islamic indices. He reports that Shariah screenings do not lead to good performance of Saudi Islamic indices.

The family of Dow Jones Islamic Market Index got attention of most earlier empirical studies and include the work of Atta (2000), Hassan (2001), Tilva and Tuli (2002), Hakim and Rashidian (2002; 2004). These studies compared the performance of Dow Jones Islamic market index (DJIM) against a conventional benchmark. However, the choice of performance measures and benchmark remain different from one researcher to another. Atta (2000) used market conventional index and 3 month risk-free rate as benchmark against DJIM and concluded superior performance of DJIM than risk-free rate and conventional index. His results are further supported by Hassan (2001) who used same benchmark with different data set (1996-2000). He documents that 6 DJIM indices are more efficient than conventional index. On the other hand, Tilva and Tuli (2002) used different conventional benchmark (S\&P 500) with different performance measure of Fama and French 3 factor model. His results show that Islamic and conventional indices are highly correlated and have no significant performance difference. Hakim and Rashidian (2000) analyzed the performance of DJIM with Wilshire 5000 and 3 moths T-Bill with weekly data set. They conclude less performance of Islamic index. Hakim and Rashidian (2004) again analyze the performance of DJIM but with different benchmark (Green Index, DJ World, Libor) with different data set (20002004). Islamic index earned inferior returns as compared to Green index (socially responsible index).

On the other hand, family of Financial Times Stock Exchange Islamic Index (FTSE Islamic Index) analyzed by Hussein (2004), Miglietta and Forte (2007), Girard and Hassan (2008) who also employed different empirical models, benchmarks and performance measures to examine the FTSE Islamic Index. Hussein (2004) uses FTSE all world and FTSE4good as benchmark against FTSE Islamic Index to compare the performance difference. He comes up with somewhat complicated results. He analyzed performance of these indices over three different intervals; bullish, bearish and entire time horizon over the period of 1996-2003. During bullish period, Islamic index outperformed its conventional counterpart, whereas during whole time period both indices perform same. Since Islamic investing is a part of socially responsible investing (SRI), Elgari (1993) and Miglietta and 
Forte (2007) compared FTSE Global Islamic index to FTSE socially responsible index by employing Sharpe's analysis (Sharpe, 1946) and co-integration techniques. They report that although Islamic index looks similar to SRI, however both are quite unique in terms of both assets allocation and econometric profile. SRI indices are exposed financial sectors whereas Islamic indices are invested in Oil \& Gas sectors. Also, there exists co-integration between 3 months Euribor and FTSE Islamic index. Another study (Hashim, 2008) compares FTSE Islamic index and SRI (FTSE 4 Good). By employing CAMP and other traditional performance measures such as Jensen's Alpha, Sharpe, and Treynor, he concludes that FTSE Islamic index is more efficient, even though more riskier than the market, and yields positive abnormal returns as compared to SRI index.

The study of Girard and Hassan (2008) is considered as a gateway into the empirical literature of Islamic indices. By employing sharp Ratio, Treynor Ratio, and Jensen's Alpha, they compared 5 FTSE Islamic indices and 5 conventional benchmarks MSCI. They also employ Fama's selectivity, net selectivity, and diversification to examine the style and timing ability of fund managers. In addition, Charhart (1997) four-factor model is used to examine the performance persistence of Islamic indices. They report insignificant performance differences between FTSE Islamic indices and their counterparts due to style and timing ability of fund managers. The results remain same even after controlling for other factors like market risk, size, book-to-market, momentum, and local and global factors. Also, there exists co-integration between Islamic and nonIslamic indices for overall period.

In addition, some studies have analyzed the performance of Islamic indices of particular countries instead of examining the performance of world's famous Islamic indices. These studies include (Ahmad and Ibrahim 2002; Nishat 2004; Dabeerru 2006; Yusof and Majid 2007; Albaity and Ahmad 2008; and Fahmi et al. 2009). For example, in Malaysia, the performance of Kuala Lampur Shariah Index (KLSI) have been analyzed by Ahmad and Ibrahim (2002), Yusof and Majid (2007), and Albaity and Ahmad (2008). No significant performance differences between Islamic and Non-Islamic indices have been reported by Ahmad and Ibrahim (2002). Also, during the bull market period, Islamic index is less performing against its conventional counterparts. Albaity and Ahmad (2008) report similar results for Kuala Lampur Shariah Index (KLSI) and Kuala Lampur Composite index (KLCI). They also examined causality between both indices and find bidirectional causality.

Recent studies on performance analysis of global Islamic indices include Guyot (2011), El Khamlichi and Sarkar (2012), Jouaber-Snoussi et al. (2012), and Arouri et al. (2013). Guyot (2011) analyzes nine Dow Jones Islamic indices (DJIM) and finds no cointegration between Islamic and non-Islamic indices. He also reports that both indices have no performance difference and efficiency \& liquidity of both indices is similar during the study period. Another study that examines efficiency of 4 Dow Jones Islamic indices is El Khamlichi and Sarkar (2012). These results about efficiency level of Islamic and non-Islamic indices are similar to those of Guyot (2011). They document that Islamic indices are as efficient as conventional MSCI and FTSE indices are. In addition, Dow Jones Islamic index and S\&P Islamic index are not co-integrated with their conventional counterparts.

Arouri et al. (2013) examines the impact of current global financial crisis on 3 Dow Jones Islamic indices to see whether Islamic finance constitute a potential solution in 
reassuring investors and stabilizing financial systems to escape from financial downturns. They employ Multivariate Vector Autoregressive (VAR) and Granger Causality test to test the interaction between Islamic and conventional financial products and specify the dependence orientation of feedback between screened and unscreened stock prices, respectively. Moreover, to ensure the best resource allocation, they develop portfolio simulation and optimal portfolio strategies (Proportional investment for both Islamic and conventional funds). They find that inverting in Islamic financial products yields higher returns and systemic risk of such portfolios, which includes Islamic financial products, is reduced significantly.

\section{Methods}

Based on review of existing literature and prime objective of this study, we are going to test following hypothesis:

$\mathrm{H}_{\mathrm{o}}$ : The return of KMI-30 index is not significantly different from its conventional counterpart (KSE-100 index)

For this purpose, four different risk-adjusted performance measures (explained below) have been used to analyze the performance differences between KMI-30 index (Shariah compliant index) and its conventional computer partKSE-100,for examining volatility effects of interest rate and exchange rate on these two indices, we have used GARCH-M model (explained below). In addition, long run performance of both Islamic and non-Islamic indices has also been analyzed.

Daily closing values of KMI-30 and KSE-100 have been collected from database of Karachi Stock Exchange for the period of July 2008 to November 2013. Daily closing value of interest rate and weighted average exchange rate is also taken from July 2008 to November 2013. The daily yield of 3 months T-Bills is used as proxy of short term interest rate and is taken from web site of State Bank of Pakistan (SBP). The daily closing value of weighted average exchange rate, measured as simple basket of equally weighted currencies (US \$, GBP, EURO), is obtained from State Bank of Pakistan (SBP). Conditional variance of interest rate series and exchange rate series represent the volatility of both series.

\section{Risk-adjusted performance measures}

For both Islamic and conventional indices risk-adjusted performance and risk measures have been computed to assess the performance of both. These risk-adjusted performance and risk measures are very common in ethical investment \& mutual fund literature. A number of notable studies, Merdad et al. (2010); Girard and Hassan (2008); Khalid Hussein (2004), have used these performance measures to compare the performance of different indices and mutual funds. Therefore, in our study we also use these performance measures to assess the performance of our indices to compare with each other. Four Performance measures are explained below:

\section{a. Jensen's Alpha}

The first performance measure used in this study is Jensen's Alpha, known as absolute risk-adjusted measure of returns. Based upon Sharpe (1964), and linter 
(1965) CAPM, Michael Jensen used Jensen's Alpha in 1970 to estimate excess returns earned by a security or a fund. The basic advantage of Jensen's alpha is that it explains whether the null hypothesis of neutral performance of an Islamic index, i.e. no screening effect or alpha is equal to zero, is statistically significant by employing t-statistics. A positive or negative value of alpha reflects superior or inferior performance of an index, respectively.

b. Sharpe Ratio

The second performance measure is Sharpe Ratio, also known as relative riskadjusted measure of returns, developed by Sharpe in 1966 and derived from Capital Market Line. The basic advantage of Sharpe measure is that it provides additional returns per unit of total risk (both systematic and un-systematic) for a security/ index. Since risk is measured by standard deviation of the index, this measure gives us trade-off between risk and return. Therefore, this ratio explains how well an investor is compensated for assuming additional risk. Higher Sharpe ratio reflects superior performance of an index.

c. Treynor Ratio

The Treynor ratio (TR) also measures the additional returns per unit of risk, but contrary to Sharpe ratio, TR Considers only systematic risk instead of both systematic and non-systematic risk. A benchmark is required for computing this relative risk-adjusted measure. TR is considered better performance measure as compared to SR since TR provided better picture of a large diversified portfolio's beta that is computed from CAPM equation.

\section{MM performance measure}

MM is an extension to Sharpe Ratio and developed by Modigliani and Modigliani in 1977. This relative risk adjusted performance measure provides an index's performance to the market in percentage terms by taking same standard deviation. Moreover, to investigate the long-run performance of all indices, this study uses two most commonly used methods; Cumulative Returns (CRs) and Buy-and -Hold Returns (BHRs), since literature shows no agreement on the appropriate methodology for computing long run returns (i.e. Brav and Gompers, 1997, Barber and lyon, 1977). The Jensen's riskadjusted return model is used to compute CRs and BHRs.

\section{Volatility measure (GARCH-M) for Shari'ah screened index and conventional indices}

To analyze the volatility effects of interest rate and exchange rate on Shariah screened index (KMI-30) and its conventional counterparts (KSE-100), GARCH-M model is utilized. This model shall also explain the risk-return trade-off for both indices. The general GARCH-M (p,q) model is described below from equations (7)-(9):

$$
\begin{aligned}
& R_{i, t}=\pi x_{t}+\gamma h_{t}+\varepsilon_{t} \\
& h_{t}=\alpha_{0}+\sum_{i=1}^{p} \alpha_{i} \varepsilon_{t-i}^{2}+\sum_{i=1}^{q} \beta_{i} h_{t-i} \\
& \varepsilon_{t} \sim N\left(0, h_{t}\right)
\end{aligned}
$$

The general GARCH (p,q)-M model is extended below with additional variables: 


$$
\begin{aligned}
& R_{m, t}=\pi_{0}+\sum_{i=1}^{n} \pi_{i} R_{m, t-i}+\theta_{1} \Delta F X_{t}+\theta_{2} \Delta I N T_{t}+y \log \left(h_{m, t}\right)+\varepsilon_{m, t} \\
& h_{m, t}=\alpha_{0}+\alpha_{1} \varepsilon_{m, t-1}^{2}+\beta h_{m, t-1}+\delta_{1} F X_{t-1}+\delta_{2} I N T_{t-1}, \\
& \varepsilon_{m, t} \sim N\left(0, h_{t}\right) .
\end{aligned}
$$

Where $R_{m, t}$ is the stocks returns of $m^{\text {th }}$ Index (KMI-30, KSE-100), $\Delta F X_{t}$ is the changes in foreign exchange rate, $\Delta I N T_{t}$ is the changes in 3 months T-Bills yield and subscript $t$ is time index for all variables. The index volatility (risk) is measured by variable $\left(h_{m, t}\right), I N T_{t-1}$ is short term interest rate volatility, $F X_{t-1}$ is foreign exchange volatility, and $\pi_{0}, \pi_{i}, \theta_{1}, \theta_{2}, \theta_{3}, \gamma, \alpha_{0}, \alpha_{1}, \beta, \delta_{1}$, and $\delta_{2}$ are parameters. Representation of volatility $\left(h_{t}\right)$ in logarithmic form is consistent with Elyasiani et al. (1995) and Lloyd and Shick (1977).

The above model is more practical than basic ARCH and GARCH models. First, it examines the impact of volatility on risk premium. Second, the inclusion of $\left(h_{t}\right)$ will examine the fundamental relationship of risk and return. If $\left(h_{t}\right)$ is significant, then there exists a relationship between risk (volatility) and returns. The sign and magnitude of this relationship, measured by $\gamma$, may be positive, negative, and zero.

\section{Results and discussion}

The daily returns earned by both Islamic and conventional indices have been depicted in Fig. 1, which clearly shows that both indices seem to move together for the time period under analysis. This trend in return series, as shown in graph, is suggesting no apparent differences in returns. However, this trend of returns is only an arbitrary deduction and requires further detailed analysis for verification.

More descriptive details on the properties of the daily returns of both indices are provided in Table 1 . The test of normality clearly shows that both return series are not normally distributed and null hypothesis of normality of data is rejected at $1 \%$ significance level by employing Jarque-Bera (JB) test statistics. In accordance with previous studies of Chorhay and Tourani (1994), Mookerjee and Yu (1999), and Hussein and

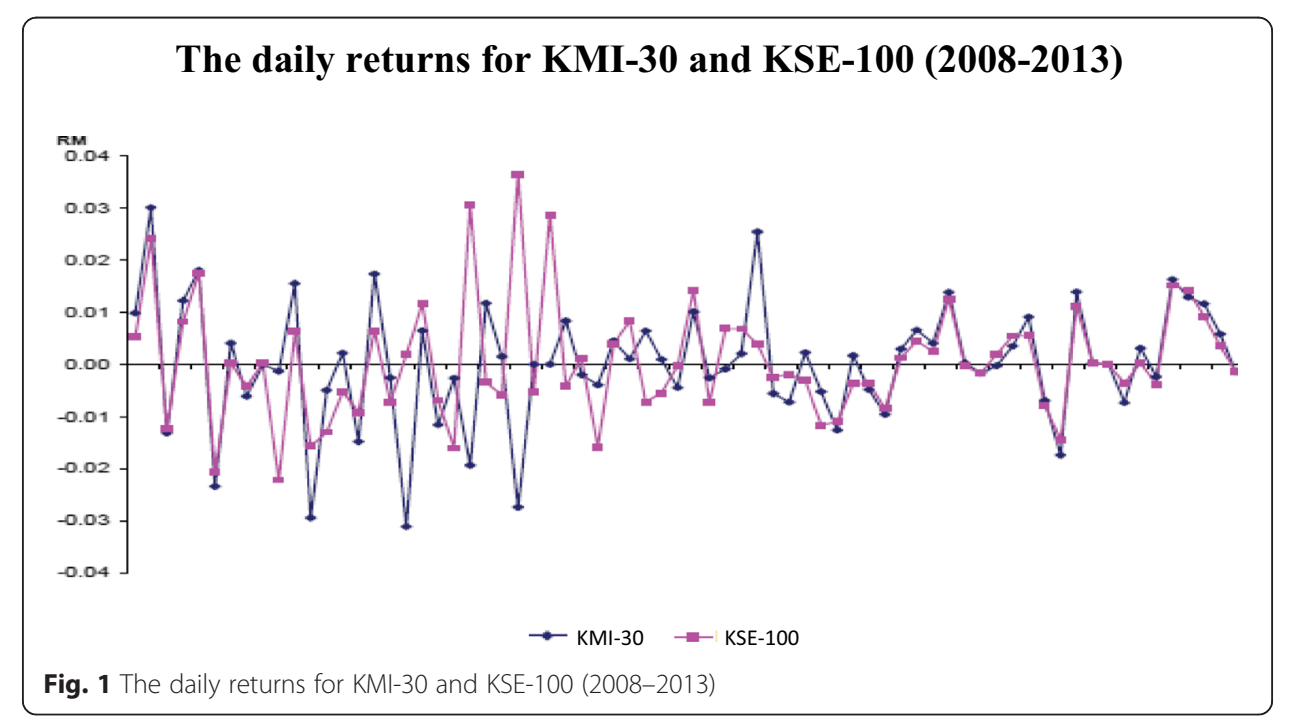


Table 1 Descriptive Statistics

\begin{tabular}{llllrrrrr}
\hline Index Name & Mean & Median & Maximum & minimum & S.D. & Skewness & Kurtosis & Jarqiue-Bera \\
\hline Conventional index (KSE-100) & 67.004 & 62.01 & 134.7 & 20.88 & 22.01 & -0.882 & 3.29 & $3322.32^{*}$ \\
Islamic Index (KMI-30) & 35.17 & 28.71 & 77.33 & 8.76 & 20.55 & -0.547 & 1.974 & $3886.09^{*}$ \\
INT (Interest Rate) & 13.12 & 10.32 & 15.3 & 1.45 & 1.94 & 0.752 & 2.87 & $4721.12^{*}$ \\
FX (Foreign Exchange) & 69.813 & 62.71 & 86 & 59.71 & 10.48 & 0.391 & 1.31 & $1573.05^{*}$ \\
\hline
\end{tabular}

Correlation between the indices $(0.86324)$

Note: *Significant at $1 \%$ level; **Significant at $5 \%$ level; ${ }^{* * *}$ Significant at $10 \%$ level

Omran (2005), our indices exhibit skewness to the left (negatively skewed) and nonsymmetric, whereas Kurtosis show positive or platy kurtic values.

The average returns (mean) of both indices are also shown in Table 1. It is clearly evident from mean values that KMI-30 earns less return (35.17) than KSE-100 return (67.004), which suggests that that we cannot reject our null hypothesis of lower returns earned by Islamic index. The lower returns earned by KMI-30 is also supported by its standard deviation (0.36754), a measurement of risk, which shows that KMI-30is less risky. Moreover, KSE-100 also shows superior long-term returns (measured by sum of all returns). Table 1 also shows correlation coefficients for both series that suggest a positive relationship between both indices. The correlation coefficient is $86 \%$, which is as strong as reported by Ahmad and Ibrahim (2002). One possible explanation of such strong correlation between both indices is that most of the stocks listed under KMI-30 are also listed under KSE-100. Therefore, both indices move together as also depicted in Fig. 1.

\section{OLS Estimation (CAPM)}

For further comprehensive analysis of indices' performance, risk-adjusted CAPM model is estimated (as described in equation 1) and results of CAPM estimation are presented in Table 2. It is clearly evident from the Table 2 that Jensen's Alpha is positive for both indices but statistically significant only for conventional index (KSE-100) at $1 \%$ level. This implies that KMI-30 yields lower returns (0.02311) against fully diversified unrestricted portfolio (0.04325). This result is consistent with the results of Hussein and Omran (2005), Girard and Hassan (2008). The results about market risk (beta) of both indices are also presented in column 3. Beta coefficients are 0.9235 and 0.9837 for KMI-30 and KSE-100, respectively. Consistent with Jouaber-Snoussi et al. (2012), this implies that KMI-30 is less risky than KSE-100, therefore KMI-30 reflects risk-return trade-off since it yields lower returns with less risk. It is also notable that beats of both indices are less than unity that implies that the two indices are less risky than the benchmark (KSE-All Shares). Further, the coefficient of determination $\left(\mathrm{R}^{2}\right)$ of KMI-30 and KSE-100 is 82.30 and $89.37 \%$, respectively. These high percentages imply that both the indices move in line with market benchmark and much of the changes in both indices are explained by market benchmark.

Table 2 CAPM Regression (t-values in parenthesis)

\begin{tabular}{llll}
\hline Index Name & Alpha & Beta & $R^{2}$ \\
\hline Conventional index (KSE-100) & $0.04325(0.0325)^{* *}$ & $0.9837(0.0000)^{*}$ & 0.89 \\
Islamic Index (KMl-30) & $0.03911(0.1321)$ & $0.9235(0.0000)^{*}$ & 0.82 \\
\hline
\end{tabular}

Note: *Significant at $1 \%$ level; **Significant at $5 \%$ level; ***Significant at $10 \%$ level 


\section{Mean difference}

Now we further proceed to test whether abnormal returns (excess daily returns) of KMI-30 are equal to zero. To test whether there is a difference between the means of both indices we have employed parametric $t$-test. The results are presented in Table 3, which clearly shows that the null hypothesis can be rejected and there is a significant difference in the mean of both indices. This result is in line with results of Girard and Hassan (2008) and Adelr and Kritzman (2008) that returns of Islamic index are significantly different from its conventional counterparts. Therefore, KMI-30 bears an extra cost on its returns due to Shari'ah screening process.

\section{Risk-adjusted performance evaluation}

To further examine the robustness of aforementioned results, the performance of both indices is re-estimated by employing other performance measures. The results are shown in Table 4 in which both indices have been ranked according to their performance. The first performance measure is Sharpe ratio that shows that KMI-30 yields lower returns (0.00401) than KSE-100 (0.00694). The next performance measure is Treynor ratio, which confirms the lower returns earned by KMI-30. The Treynor ratio takes into consideration only systematic risk (beta), whereas Sharpe ratio incorporates both systematic and unsystematic risks. In both performance measures KMI-30 is ranked behind KSE-100. The Jensen's Alpha and MM performance measures further confirm the results found by other measures. MM shows that KMI-30 earns lower returns (0.0387) than KSE-100 (0.0532). These results are consistent with those of Cummings (2000) and Ahmad and Ibrahim (2002). One possible explanation that can be attributed to the fact that KMI-30 earns lower returns is the inclusion of large market capitalization in KSE-100, which consists of 100 securities, whereas KMI-30 includes only 30 Shariah compliant stocks. Therefore, according to Cleassens, Dasgupta and Glen (1995), there is a positive relationship between returns on investment and the size of investment for less developed economies including Pakistan.

In addition, by employing Cumulative Returns (CR) and Buy-and-Hold returns (BHR) methods, long-run performance of both indices is examined. Consistent with our previous findings of short-run performance, Table 5 shows that KSE-100 outperforms its Islamic counterpart in the long-run. The parameters of long-run performance (CR: 0.334 and BHR: 0.193) for KSE-100 shows superior long-run performance. To sum up, the findings of this study show that application of Shariah screens do have an adverse impact on the performance of KMI-30. Hence, KMI-30 yields lower returns as compared to KSE-100 and $t$-test of mean returns of both indices is statistically significant.

\section{Estimated conditional returns with $\operatorname{GARCH}(1,1)$ Model}

This section explains the empirical results about parameters of conditional returns based on the empirical models, equation 4 to 6 . Panel A of Tables 7 and 8 presents the

Table 3 Differences in Mean between KMI-30 and KSE-100 (t-test)

\begin{tabular}{lcc}
\hline Mean Difference & t-value & $P$-value for $t$-test \\
\hline 0.0001 & 5.58 & $(0.0423)^{* * *}$ \\
\hline
\end{tabular}

Note: Numbers in parentheses are P-values. **shows significance at $5 \%$ level 
Table 4 Risk-Adjusted Performance Evaluation

\begin{tabular}{lcccc}
\hline Index Name & Sharpe Ratio & Treynor Ratio & Jensen's Alpha & MM \\
\hline Conventional index (KSE-100) & 0.00694 & 0.00076 & 0.0156 & 0.0387 \\
Islamic Index (KMI-30) & 0.00401 & 0.00002 & 0.0032 & 0.0532 \\
\hline
\end{tabular}

results of conditional mean equation (4) with GARCH $(1,1)$, whereas, panel B shows the results of conditional variance equation (5) that exerts the impact of conditional volatilities of both exchange rate and interest rate on conditional volatilities of both KSE-100 and KMI-30. Table 6 shows the result of Augmented Dickey Fuller test (ADF) and Phillips-Peron test (PP) for each stock return series and other variables. The series are non-stationary at level but becomes stationary at first difference. Therefore, we use first differenced series in our analysis.

The first column of Tables 7 and 8 reports the results of ARCH effect for each stock return series. Both Islamic and conventional index show significant results at $1 \%$ level of significance. Therefore, we reject $\mathrm{H}_{\mathrm{o}}$ of no heteroskedasticity which is the evident of ARCH effect. The squared residual series of both Islamic and conventional index show presence of residual autocorrelation, which shows failure of classical constancy assumption about constant variance of error term. Therefore, the classical OLS coefficients cannot be estimated efficiently and standard errors could also be wrong and only the ARCH type models are appropriate for analyzing such type of series.

It can be seen from Panel "A" of Tables 7 and 8 that conventional index (KSE-100) is significantly affected by the changes in interest rate and exchange rate. The estimated parameters for exchange rate and interest rate are 0.659 and 0.0033 , respectively. This result fits well with stock valuation model that argues that discounted present values of a firm's future cash flows are represented in stock prices. The stock prices usually reduce with an increase in interest rate and eventually the returns. Therefore, it can be safely said that changes in interest rate is a major factor behind the instability of conventional stock index and, accordingly, investors are also more sensitive towards fluctuations in interest rate. Perhaps, the conventional stock market must be stabilized by the government by controlling interest rate. This finding is consistent with the study Yusof and Majid (2007) who document that Malaysian conventional market is affected by higher interest rate.

On the other hand, as shown in Panel A, for Islamic index (KMI-30), interest rate is not a significant factor to predict the excess returns. The tenet of Islamic principles is highlighted by the findings that interest rate is not a determining variable in explaining KMI-30's volatility. Whereas, KIM-30 is significantly affected by the changes in exchange rate whose estimated parameter is 0.6619 . On the whole, it is found that $22 \%$ of the volatilities in exchange rate and interest rate can predict the volatility of KMI-30 with volatility in exchange rate remain the most significant. Whereas, for KSE-100, the

Table 5 Long-Run Performance of KMI-30 and KSE-100

\begin{tabular}{lcc}
\hline Index Name & Cumulative Returns & Buy-and-Hold Returns \\
\hline Conventional index (KSE-100) & $0.4886(2.53)^{* *}$ & $0.6985(3.93)^{* *}$ \\
Islamic Index (KMl-30) & $0.2641(-0.036)$ & $0.5543(0.041)$ \\
\hline
\end{tabular}

Note: Numbers in parentheses are t-values * Significant at $1 \%$ level; ** Significant at $5 \%$; level ${ }^{* *}$ Significant at $10 \%$ level 
Table 6 Unit-Root Analysis

\begin{tabular}{lllllll}
\hline Augmented Dickey Fuller & & & & Phillips-Peron & \\
\cline { 1 - 2 } Index Name & At Level & At Difference & & At Level & At Difference \\
\hline Conventional index (KSE-100) & $-2.132(0.2319)$ & $-48.251(0.0001)$ & & $-2.120(0.2366)$ & $-49.54(0.0001)$ \\
Islamic Index (KMI-30) & $-0.6051(0.8670)$ & $-47.1839(0.0001)$ & & $-0.6437(0.858)$ & & $-47.187(0.0001)$ \\
FX (Foreign Exchange) & $0.3045(0.9785)$ & $-11.4329(0.0000)$ & & $-0.5389(0.9880)$ & $-32.8513(0.0000)$ \\
INT (Interest Rate) & $-1.3531(0.6065)$ & $-22.2255(0.0000)$ & & $-3.2041(0.0199)$ & $-133.068(0.0000)$ \\
\hline
\end{tabular}

Note: Numbers in parentheses are $P$-values

predictive power of both interest rate and exchange rate volatility is increased from 22 to $29 \%$. Muslim investors around the globe do not want to maximize their profits but are also concern whether stocks are Shariah compliant.

Over the last decade, there has been immense growth in literature that investors go beyond maximizing results and that they are concern with ethical dimensions of their investments. Therefore, interest rate is not a decisive factor in the context of Pakistani investors who seek to invest in KMI-30. Moreover, the exchange rate is found to be a determining factor for volatility of KMI-30. Hence changes in volatility of returns of KMI-30is significantly produced by the changes in macroeconomic conditions like exchange rate. In addition, interest rate alone is not responsible for stock market volatility but also the exchange rate. Both conventional and Islamic stock indices must be stabilized by the government agencies by designing and implementing suitable policies.

The last column of Panel A shows the result for theory of risk-return trade-off. The relationship of risk-return trade-off is measured by the coefficient Gamma $(\gamma)$. The relationship of risk $\gamma$ and stocks returns, as expected, is positive and statistically significant for both KMI-30 and KSE-100. This result is in line with the theory of risk-return trade-off and is consistent with previous results of Yusof and Majid (2007). In simple words, whenever there is higher risk assumed by the investors, there is higher return. The implication of the positive relationship is that investors do consider risk associated with individual stock index and expect to be compensated with higher returns when higher risk is assumed. Although every investor has different risk preferences, some are risk-averse and others are risk-seekers, however, every investor expects higher return when he assumes higher risk.

Panel B of Tables 7 and 8 reports the results about conditional variance equation in which impact of exchange rate volatility \& interest rate volatility on both indices' stock returns volatility is examined. In conditional variance equation, $\alpha_{0}$ is intercept term. The time-invariant component in the stock returns of both conventional and Islamic index volatility is shown by the result of intercept term $\left(\alpha_{0}\right)$. The positive and statistically significant value of $\alpha_{0}$, in both cases, show that stocks returns of KMI-30 and KSE-100 are highly volatile in nature and contain time-invariant component. This implication further strengthens the choice of using ARCH type models to analyze volatility of both indices' returns. In conditional variance equation, both $\alpha_{1}$ and $\beta$ represents $\mathrm{ARCH}$ and GARCH terms, respectively. Both the ARCH and GARCH parameters are positive, which satisfies the non-negativity condition, and are statistically significant for KMI-30 and KSE-100. The ARCH parameter $\alpha_{1}$ describes the impact of last period's shock on volatility, whereas GARCH parameter $\beta$ shows the impact of previous period's variance on both indices' stock return's volatility. Although both the parameters, ARCH 
Table 7 Estimated Conditional Returns with $\operatorname{GARCH}(1,1)$

$R_{m, t}=\pi_{0}+\sum_{i=1}^{n} \pi_{i} R_{m, t-i}+\theta_{1} \Delta F X_{t}+\theta_{2} \Delta / N T_{t}+\gamma \log \left(h_{m, t}\right)+\varepsilon_{m, t}$

Panel A (Conditional Mean Equation)

\begin{tabular}{|c|c|c|c|c|c|c|c|}
\hline Index Name & $\mathrm{ARCH}(1)$ & $\pi_{0}$ & $\pi_{i}$ & $\theta_{1}$ & $\theta_{2}$ & y & Adjusted $R^{2}$ \\
\hline Conventional index (KSE-100) & $63.2085(2.342)^{*}$ & $9.2404(12.765)^{* * *}$ & $0.082(23.983)^{*}$ & $0.659(-21.265)^{* *}$ & $0.0033(24.76)^{* * *}$ & $1.682(21.87)^{* *}$ & 0.2973 \\
\hline Islamic Index (KMI-30) & $\left.34.8262(12.84)^{*}\right)$ & $4.2196(-1.543)^{* *}$ & $0.0049(41.874)^{*}$ & $0.6619(17.65)^{* *}$ & 0.6619 (2.543) & $2.4321(1.042)^{*}$ & 0.2234 \\
\hline
\end{tabular}

Where $R_{m, t}$ is the stocks returns of $m^{\text {th }}$ Index (KMI-30, KSE-100), $\Delta F X_{t}$ is the changes in foreign exchange rate, $\Delta I N T_{t}$ is the changes in 3 months T-Bills yield and subscript tis time index for all variables. The index volatility

(risk) is measured by variable $\left(h_{m, t}\right)$, and $\pi_{0,}, \pi_{i}, \theta_{1}, \theta_{2,}, \theta_{3}, \gamma$ are parameters. Representation of volatility $\left(h_{t}\right)$ in logarithmic form is consistent with Elyasiani et al. (1995) and Lloyd and Shick (1977)

Note: Numbers in parentheses are t-values * Significant at $1 \%$ level; ** Significant at $5 \%$ level; *** Significant at $10 \%$ level 
Table 8 Volatility estimates

\begin{tabular}{|c|c|c|c|c|c|c|}
\hline \multicolumn{7}{|c|}{$\begin{array}{l}h_{m, t}=a_{0}+a_{1} \varepsilon_{m, t-1}^{2}+\beta h_{m, t-1}+\delta_{1} F X_{t-1}+\delta_{2} / N T_{t-1} \\
\text { Panel B (Conditional variance Equation) }\end{array}$} \\
\hline Index Name & $a_{0}$ & $a_{1}$ & $\beta$ & $a_{1}+\beta$ & $\delta_{1}$ & $\delta_{2}$ \\
\hline \multirow[t]{2}{*}{ Conventional index (KSE-100) } & 39.7251 & 0.93999 & 0.0044 & 0.2499 & 0.51419 & 0.36302 \\
\hline & $(1.322)^{*}$ & $(9.412)^{*}$ & $(-23.74)^{*}$ & (19.52) & $(64.921)^{*}$ & $(28.32)^{*}$ \\
\hline \multirow[t]{2}{*}{ Islamic Index (KMI-30) } & 53.9856 & 0.7996 & 0.2247 & 0.0486 & 6.3333 & 0.5941 \\
\hline & $(1.180)^{*}$ & $(1.850)^{*}$ & $(13.854)^{*}$ & $(0.520)$ & $(18.95)^{*}$ & $(0.2391)$ \\
\hline
\end{tabular}

The index volatility (risk) is measured by variable $\left(h_{m, t}\right), I N T_{t-1}$ is short term interest rate volatility, $F X_{t-1}$ is foreign exchange volatility, and $a_{0}, a_{1}, \beta, \delta_{1}$ and $\delta_{2}$ are parameters

Note: Numbers in parentheses are t-values* Significant at $1 \%$ level; ** Significant at $5 \%$ level; *** Significant at $10 \%$ level

$\alpha_{1}$ and $\mathrm{GARCH} \beta$, are statistically significant for both indices, however, in magnitude, ARCH parameter $a_{1}$ is smaller than the GARCH parameter $\beta$. This implication shows that volatility of both indices are more sensitive to its own lagged value than it is to new surprises. In other words, the impact of previous period's forecast variance is more persistence on the stock return's volatility of both indices. The volatility persistence is measured by the sum of ARCH and GARCH parameters $\left(a_{1}+\beta\right)$. The sum $\left(a_{1}+\beta\right)$ is less than unity, in all cases, which implies the stationarity of the models. The larger value of the sum $\left(a_{1}+\beta\right)$ shows that shocks to stock returns of both indices persist for a longer time period and its effects remain highly persistent in the following periods.

Consistent with Elyasiani et al. (1995) and Kasman et al. (2011) this finding implies that results regarding volatility effects on returns of both indices. The impact of exchange rate volatility on the stock returns is measured by the coefficient $\delta_{1}$. The results show that parameter of exchange rate volatility $\delta_{1}$ is positive and statistically significant for both KMI-30 and KSE-100. This implies that, whenever exchange rate volatility increases, stock returns of both indices become more volatile in following periods. Pakistan is an import-oriented country and always exposed to the risk of foreign exchange fluctuations due to the globalization of banking sector. Therefore, higher exchange rate volatility leads towards higher fluctuations in the stocks returns of both indices. Another possible reason for higher fluctuations in the stock returns, due to exchange rate volatility, is the change in Pakistani political setup in 2008 (from dictatorship to democracy), after which exchange rate increased rapidly Hence, overall, KMI-30 and KSE-100 stock return's volatility is increased in response to exchange rate volatility. The impact of interest rate volatility on stock return's volatility is measured by the coefficient $\delta_{2}$. Consistent with Kasman et al. (2011) the parameter of interest rate volatility $\delta_{2}$ is positive and statistically significant only for KSE-100. This implication shows that, in response to increased interest rate volatility, the stock return's volatility of KSE-100 becomes more volatile in the subsequent periods. Pakistani financial markets lack financial derivatives instruments that can prevent stock returns becoming more volatile in response to interest rate volatility. This result further support our previous result of conditional mean equation which shows that, for Islamic index (KMI-30), interest rate is not a determining factor behind conditional volatilities of KMI-30.

\section{Conclusion}

Some of the financial and academic experts around the globe still hold a question mark on the economic viability of the ethical investing. Prime arguments given by the opponents of ethical investing include restricted diversification, availability of smaller 
investment universe, and additional screening and monitoring cots are. Hence, ethical investing criteria may adversely impact the performance of an investment. On the other hand, advocates of socially responsible investment come up with an argument that a competitive advantage can be achieved with good corporate responsibility practices, which can offer firms a range of opportunities. Accordingly, there is scarcity in the empirical literature on ethical investing and somewhat inconsistent results are provided by the available empirical papers.

The prime objective of this study was to investigate the extent to which the conditional volatilities of both Shariah compliant stock index (KMI-30) and conventional stock index (KSE-100) in Pakistan are related to the conditional volatility of interest rate and exchange rate. We employed Generalized Autoregressive Conditional Heteroskedastic in the mean (GARCH-M) model. This framework relaxes constancy assumption of classical linear regression (CLRM) model and allows exchange rate and interest rate volatility to evolve over time. The GARCH-M framework also reveals results about risk-return trade-off in the context of both Islamic and conventional stock indices. The findings show positive and statistically significant effect of interest rate volatility on KSE-100, whereas KMI-30 remains unaffected by the same. The relationship of risk coefficient $(\gamma)$, measured in conditional mean equation (GARCH-M), and stocks returns is positive and statistically significant for both KMI-30 and KSE-100, as expected. This result is consistent with the theory of risk-return trade-off.

In addition, this study also aims at investigating performance ofKMI-30 and KSE-100 using popular risk-adjusted performance measures. KMI-30 is marginally underperforming KSE-100 as indicated by our statistical results on risk and returns, measured by mean and standard deviation, respectively. KMI includes 30 Shariah compliant stocks, while, KSE-100 includes 100 securities that represent large market capitalization. One possible reason of marginal underperformance of KMI-30 might be because of its relative newness (since it was launched in 2008) and other reason might be because in less developed countries, size and returns are positively related. Therefore, Islamic investors are not substantially worse-off than conventional investors who seek to invest in un-screened stocks. Moreover, KSE-100 has higher returns and higher beta (systematic risk) as shown by the results of risk-adjusted returns for four performance measures. Opposite is true for KMI-30that confirms the theory of finance where higher risk assumed by investors will yield higher returns and vise verse. Muslim investors might have lower returns in the short run; however, such investments yield some other rewards in the world hereafter. Shariah investors want maximize their investment returns but they also want peace of mind by aligning their investments with their religious beliefs. On the whole, this study finds no significant performance differences and movements of both indices. Both indices are behaving in a similar direction for short and long run as well.

The empirical findings of this study reveal important information\& policy implications for individual \&institutional investors, regulatory authorities, academic community, and particularly for those who wish to make alignment between their investments and religious \&ethical beliefs through ethically responsible investments. Expected or unexpected movements in exchange rate and interest rate must be analyzed closely, by the portfolio managers and other stakeholders, for developing risk management strategies. Further research must be initiated by examining impact of other macroeconomic factors, such as inflation and GDP, on the risk-return characteristics of both KMI-30 and KSE-100. 


\section{Competing interests}

Authors of the paper understand "Financial Innovation" Journal Policy on declaration of interests and declare that they have no competing interests.

\section{Authors' contributions}

First Author Contribution: First Author (Mohammad Ejaz Rana) has collected and analyzed the data and prepared the first draft of the article.

Second Author Contribution: Second Author (Waheed Akhter) has revised the first draft and made necessary changes in abstract, introduction and conclusion to match results with the objectives of the study and to highlight contribution of the research. Both authors read and approved the final manuscript.

\section{Authors' information}

Mohammad Ejaz Rana is a PhD scholar at Department of Management Sciences, COMSATS Institute of Information Technology, Lahore, Pakistan

Dr. Waheed Akhter is Assistant Professor, Department of Management Sciences, COMSATS Institute of Information Technology, Lahore, Pakistan. His areas of interest are Islamic banking, Takaful (Islamic Insurance) and Risk Management. He has authored one book and published 20 research papers in various international journals.

\section{Acknowledgements}

The authors are grateful to the officials of state bank of Pakistan (SBP) for helping in accessing the relevant data regarding Islamic and conventional stock indices. We are grateful to the staff of COMSATS institute of information technology for secretarial assistance.

Received: 5 June 2015 Accepted: 11 November 2015 Published online: 02 December 2015

\section{References}

Adler T, Kritzman M (2008) The cost of socially responsible investing. J Portfolio Management 35:52-56

Ahmad Z, Ibrahim H (2002) A Study of Performance of The KLSE Syariah Index. Malays Manage J 6(1 \& 2):25-34

Albaity M, Ahmad R (2008) Performance of Syariah and Composite Indices: Evidence from Bursa Malaysia. Asian Acad Manage J Account Finance 4(1):23-43

Arouri MEH, Ben Ameur H, Jawadi F, Jawadi N, Louhichi W (2013) Are Islamic finance innovations enough for investors to escape from a financial downturn? Further evidence from portfolio simulations. Appl Econ 45(24):3412-3420

Atta H (2000) Ethical rewards. M.Sc. University of Durham, United Kingdom, Retrieved March 11, 2012, from http:// citeseerx.ist.psu.edu/viewdoc/download?doi=10.1.1.198.5019\&rep=rep1\&type=pdf

Carhart M (1997) On persistence in mutual fund performance. J Finance 52(1):57-82

Claessens S, Dasgupta S, Jack G (1995) Return behaviour in emerging Stock Market. World Bank Economic Rev 9(1): $131-151$

Cummings L (2000) The Financial Performance of Ethical Investment Trusts": An Australian Perspective'. J Business Ethics 25:79-92

Dabeerru RN (2006) Performance of Mutual Funds in Saudi Arabia., Retrieved August 24, 2013, from Social Science Research Network (SSRN): http://ssrn.com/abstract=921523

Dharani M, Natarajan P (2011) Equanimity of Risk and Return Relationship between Shari'ah Index and General Index in India. J Econ Behav Stud 2(5):213-222, May 2011, Dubai, UAE

El Khamlichi A, K. Laaradh (2012) "Performance persistence of Islamic Equity Mutual Funds", International Islamic Capital Market Conference, 19-20 June 2012, Jakarta, Indonesia

El Khamlichi A, HK Sarkar (2012) How Islamic equity indices are diversified and efficient as compared to their conventional counterparts? Evidence from major global index families, JEBO Islamic Finance Conference, September 29th - October 1st, Birmingham, United-Kingdom.

Elgari M (1993) Towards an Islamic Stock Market. Islamic Economic Studies 1(1):1-20

Elyasiani E, Kopecky K, Vanhoose D (1995) Cost of Adjustment, Portfolio Separation, and the Dynamic Behavior of Bank Loans and Deposits. Journal of Money, Credit, and Banking 27(I):955-974

Fahmi A-R, Noryati A, Ismail A (2009) Information transmission between Islamic stock indices in South East Asia. Int J Islamic Middle Eastern Finance Manage 2(1):7-19

Fama E, French K (1998) Taxes, Financing Decisions, and Firm Value. J Financ 53(3):819-843

Fowler SJ, Hope C (2007) A critical review of sustainable business indices and their impact. J Bus Ethics 76(3):243-252

Girard E, Hassan MK (2005) Faith-Based Ethical Investing: The Case of Dow Jones Islamic Indices. FMA Annual Meeting, Chicago, USA

Girard EC, Hassan MK (2008a) Is there a cost to faith-based investing: Evidence from FTSE Islamic indices. J Investing 17(4):112-121

Girard E, Hassan MK (2008b) Is There a Cost to Faith-Based Investing: Evidence from FTSE Islamic Indices. J Investing 17(4):112-121

Guyot A (2011) Efficiency and Dynamics of Islamic Investment: Evidence of Geopolitical Effects on Dow Jones Islamic Market Indexes. Emerg Markets Finance Trade 47(6):24-45

Hakim S, Rashidian M (2000) Risk \& return of Islamic stock market indexes. 9th Economic Research Forum Annua Conference, 26-28 October, Sharjah, United Arab Emirates

Hakim S, M Rashidian (2002) Risk \& return of Islamic stock market indexes. 9th Economic Research Forum Annual Conference, 26-28 October, Sharjah, United Arab Emirates.

Hakim S, M Rashidian (2004) How Costly is Investors' Compliance to Sharia? 11th Economic Research Forum Annual Conference, 14-16 December, Sharjah, United Arab Emirates 
Hashim, N. (2008), The FTSE Global Islamic and the Risk Dilemma, AIUB Bus Econ Working Paper Series, retrieved on June 16, 2012 from http://core.ac.uk/download/pdf/6505608.pdf

Hassan MK (2001) Risk, Return and Volatility of Faith-based Investing: the Case of DJIM. Fifth Harvard University Forum on Islamic Finance, October 6-7, Boston, USA

Hoepner AG, Rammal HG, Rezec M (2011) Islamic mutual funds' financial performance and international investment style : evidence from 20 countries. European Journal of Finance 17(no. 9-10):829-850

Hussein K (2004) Ethical Investment: Empirical Evidence from FTSE Islamic Index. Islam Econ Stud 12(1):21-40

Hussein K, Omran M (2005) Ethical Investment Revisited: Evidence from Dow Jones Islamic Indexes. J Investing 14(3): $105-124$

Jensen MC (1968) The performance of mutual funds in the period 1945-1968. Journal of Finance 23(2):389-416

Jouaber-Snoussi K, Ben Salah M, Rigobert M-J (2012) The Performance of Islamic Investment: Evidence from the Dow Jones Islamic Indexes. Bankers, Markets and Investors 121:4-16

Kasman S, Vardar G, Tunç G (2011) The impact of interest rate and exchange rate volatility on banks' stock returns and volatility: Evidence from Turkey. Economic Modelling 28:1328-1334

Lloyd WP, Shick RA (1977) A Test of Stone's Two-Index Model of Returns. J Financial and Quantitative Analysis 12:363376

Merdad H, Hasan MK, Alhenawi Y (2010) Islamic Versus Conventional Mutual Funds Performance in Saudi Arabia: A Case Study. Islamic Economics 23:2

Miglietta F, Forte G (2007) Islamic Mutual Funds as Faith-Based Funds in a Socially Responsible Context. Luigi Bocconi University, Milan

Miller M (1977) Debt and Taxes. Journal of Finance 32:261-275

Mookerj ee, Raj en and Qiao Yu (1999) An empirical analysis of the equity markets in China. Review of Financial Economics; 8, 41-60.

Myers SC (1993) Still Searching for Optimal Capital Structure. J Appl Corp Finance 39:4-14

Naughton S, Naughton T (2000) Religion, ethics and stock trading: the case of an Islamic equities market. J Bus Ethics 23(2):145-159

Nishat M (2004) Experience of Equity-based Islamic Shares in Pakistan. Pak Dev Rev 41(2):583-602

Sharpe WF (1964) Capital Asset Prices: A Theory of Market Equilibrium under Conditions of Risk. J Finance 19(3):425442

Sharpe W (1966) Mutual Fund Performance. J Business 39(1):119-138

Shyam-Sunder L, Myers SC (1999) Testing the Static Trade-off against Pecking Order Models of Capital Structure". J Financial Economics 51:219-244

Tilva R, Tuli J (2002) Islamic Banking: A new era of financing., Retrieved March 28, 2012, from http://www. globalwebpost.com/faroogm/study_res/i_econ_fin/tilva_tuli_ibanking

Treynor J, Mazuy K (1965) Can mutual funds outguess the market? Harv Bus Rev 44:131-136

Yusof RM, Majid MSA (2007) Stock Market Volatility Transmission in Malaysia: Islamic Versus Conventional Stock Market. J KAU: Islamic Econ 20(2):17-35, Conference Presentations

\section{Submit your manuscript to a SpringerOpen ${ }^{\circ}$} journal and benefit from:

- Convenient online submission

Rigorous peer review

- Immediate publication on acceptance

- Open access: articles freely available online

- High visibility within the field

- Retaining the copyright to your article 